\title{
Locating Charles d'Orléans: In France, in England and Out of Europe
}

\author{
Rory G. Critten
}

The poetry of Charles d'Orléans (1394-1465) cannot easily be incorporated into the pattern of traditional literary history, which requires that an author's national and linguistic allegiances be identical and exclusive. Born in Paris in 1394, Charles spent the first twenty-one years of his life in France; following his capture at the Battle of Agincourt, in 1415, he spent twenty-five years in England; after his release in 1440 he spent the last twenty-five years of his life back on the Continent. 'The duke's writing cuts across these temporal divisions. During his English captivity, as well as continuing to write lyrics in French, Charles apparently learned English and began to compose poetry in that language too, sometimes in parallel with his French texts, sometimes in independent work that has no surviving French equivalent. ${ }^{2}$ Before his repatriation, the duke oversaw the production of at least two manuscripts of his verse: one book, now London, British Library, MS Harley 682, which brought together his English writings,

* A preliminary version of this chapter was presented at the eleventh Medieval Translator conference in Vienna (2017). I am grateful for the thoughtful feedback that I received on that occasion, in particular from Denis Renevey, David Wallace and Christiania Whitehead.

1 The standard biography remains Pierre Champion, Vie de Charles d'Orléans (Paris, 1911).

2 See Fortunes Stabilnes: Charles of Orleans's English Book of Love, ed. Mary-Jo Arn, Medieval and Renaissance Texts and Studies 138 (Binghamton, 1994). Citations of the English verse will be from this edition by poem and line number (the poems are lineated continuously). I follow Arn in assuming Charles's authorship of the English poetry, but am less inclined to see him as solely responsible for the English Book of Love. See further Rory G. Critten, Author, Scribe, and Book in Late Medieval English Literature (Cambridge, 2018), 164-66.

New Medieval Literatures 20 (2020) 
and another, now Paris, Bibliothèque nationale de France, MS fr. 25458, which collected his French texts. ${ }^{3}$ On his return to France, Charles wrote a flurry of new French poems, while, at the same time, he fostered the writing of guests and dependents at his court at Blois; their texts were added to MS fr. 25458, which gradually developed into a sort of logbook recording the poetic conversations that criss-crossed Charles's household. ${ }^{4}$ Finally, towards the end of his life, Charles tasked his Italian secretary, Antonio Astesano, to produce another book - now Grenoble, Bibliothèque municipale, MS 873 - that would memorialize his French verse by presenting it alongside a parallel Latin translation. ${ }^{5}$ The careful organization and decoration of the Grenoble manuscript make manifest the literary ambitions of a man for whom writing poetry was a life-long pursuit and whose identity as a poet and as the anthologist of his own verse formed a cornerstone of his princely self-presentation. ${ }^{6}$

3 On the joint commissioning of these books, see Mary-Jo Arn, 'Two Manuscripts, One Mind: Charles d'Orléans and the Production of Manuscripts in Two Languages (Paris, BN MS fr. 25458 and London, BL MS Harley 682)', in Charles d'Orléans in England (1415-1440), ed. Mary-Jo Arn (Cambridge, 2000), 61-78.

4 See Poetry of Charles d'Orléans and His Circle: A Critical Edition of BnF MS. fr. 25458, Charles d'Orléans's Personal Manuscript, ed. John Fox and Mary-Jo Arn, Medieval and Renaissance Texts and Studies 383 (Turnhout, 2010). Citations of Charles's French poetry are by poem number (or title) and line number from this edition (the poems are lineated individually). In order to facilitate reference across the editions of the French poetry that are currently available, I also give the first line of each of the poems mentioned. Translations from French are my own.

5 The only recent study of this book is the groundbreaking account in A. E. B. Coldiron, Canon, Period, and the Poetry of Charles d'Orléans: Found in Translation (Ann Arbor, MI, 2000), 112-44. The French poems in the Grenoble manuscript were edited twice in the nineteenth century, most recently by Aimé Champollion-Figeac, as Les Poésies du duc d'Orléans (Paris, 1842). Astesano’s Latin translations remain unedited. The Grenoble manuscript has been digitized and may be viewed online at http://pagella.bm-grenoble.fr.

6 On Charles's self-presentation as the anthologist of his English verse, see Critten, Author, Scribe, and Book, 149-58; and Denis Renevey, "Short song is good in ale": Charles d'Orléans and Authorial Intentions in the Middle English Ballade 84', in Middle English Lyrics: New Readings of Short Poems, ed. Julia Boffey and Christiania Whitehead (Cambridge, 2018), 201-10. In this connection, discussing the French poetry, see too Lucas Wood, 'Charles d'Orléans's Heart and Its Books', Medium Ævvum 87 (2018), 343-67. 
In this chapter, I reflect on the expression that Charles's transnational, trans-linguistic identity achieves in his French and English poetry. In so proceeding, I follow in the footsteps of scholars such as Ardis Butterfield and Jonathan Hsy, who have already done much to resituate Charles's work against the backdrop of the Hundred Years War and the shifting geo-political situation sustained by its long prosecution. ${ }^{7}$ What I want to add to Butterfield's and Hsy's accounts is an appreciation of the deliberate ways in which Charles mobilizes his unique biography in order to curry favour across audiences in England and on the Continent. In what follows, I do not view Charles's references to his linguistic and geographic diversity primarily as moments of selfrevelation or auto-examination. Here I follow both Michel Zink, who points out that unguarded self-exposure would leave a man in Charles's position vulnerable, and Jean-Claude Mühlethaler, who points out that, like Petrarch, Charles expresses scorn in his verse for those incapable of mastering their emotions. ${ }^{8}$ Instead, I interpret Charles's gestures towards his English experience as aspects of a public persona that the duke carefully fashioned and refashioned to meet local requirements that changed over the course of his career.

I begin with a re-examination of Charles's rondel 179 ('Le trucheman de ma pensee'), a poem that is central in the analyses of both Butterfield and Hsy. My aim is to demonstrate the performative and comic dimensions of the text, which I view as reflective of the relatively free atmosphere of its production in Charles's court at Blois. Next, turning back in time to consider the poetry that the duke wrote in England, I begin by registering the discrepancy in Charles's French prison poetry between works that refer to the poet's incarceration only glancingly, via the allegorical repertories made available by the duke's literary predecessors, and those compiled among the 'balades de plusieurs propos' in which Charles addresses his situation more directly. Here

7 Both discussed below. See Ardis Butterfield, The Familiar Enemy: Chaucer, Language, and Nation in the Hundred Years War (Oxford, 2009), 304-7; and Jonathan Hsy, Trading Tongues: Merchants, Multilingualism, and Medieval Literature (Columbus, OH, 2013), 79-87 and 194-209.

8 See Michel Zink, “Mis pour meurir ou feurre de prison”: le poète, leurre du prince', in Guerre, pouvoir et noblesse au Moyen Âge: mélanges en l'honneur de Philippe Contamine, ed. Jacques Paviot and Jacques Verger, Cultures et civilisations médiévales 22 (Paris, 200o), 677-85; and Jean-Claude Mühlethaler, Charles d'Orléans, un lyrisme entre Moyen Âge et modernité, Recherches littéraires médiévales 3 (Paris, 2010), 157-74. 
too considering the poetry from the perspective of its first audiences is helpful. Drawing on Pierre Champion's seminal work on the transmission history of Charles's French poetry as well as on my own reassessment of some of the surviving manuscript evidence, I demonstrate the likelihood that Charles attempted to organize the circulation of two different collections of his French prison poetry around the time of his release, one including his more politically engaged poetry, the other excluding it. I argue that Charles deliberately withheld his political poetry from broad circulation among his insular audience, to whom he presented himself as a model courtly lover after the French literary tradition; for a continental readership, by contrast, the duke prepared a compilation of his works that included his more politically engaged texts and that presented him as an active player on the international stage. This reassessment of Charles's French prison poetry allows for a corresponding reconsideration of the selection and translation choices that produced the English collection of the duke's verse. I view these choices as reflective of a general attempt on Charles's part to depoliticize his public image among the English.

My broader argument, which considers the social and political instrumentality of Charles's writing, affords a fresh perspective on one of the more striking discrepancies between the duke's French and English texts. In the French text of his ballade 35, Charles makes a conventional reference to his lady as 'celle que l'en doit nommer / Par droit la plus belle de France' [she who must be named / Rightfully the most beautiful in France] (B35: 6-7); in the English version of this text, by contrast, she appears as 'hir that ought ben callid trewly / The most fayrist bitwene this and Europe' $\left(B_{35}\right.$ : 6-7). I close with a consideration of Charles's use of the word Europe in the English poem, focusing on the significance of the distinction that the poet draws between Europe and 'this' - England, the land of his captivity. What does it mean for Charles to evoke an isolated England in the context of his prison poetry? If the idea flies in the face of his own experience, how might it serve the more cynical purposes of an address to his captors? Through consideration of these and related questions, I hope to show that Charles's writing still has much to tell us about the possible medieval relationships between poetry, place and politics. 


\section{In France}

In their analyses of Charles's depiction of his trans-national, translinguistic identity, both Butterfield and Hsy turn to Charles's French rondel 179. It is a rich and complex text, so I cite it in full:

Le trucheman de ma pensee,

Qui parle maint divers langaige,

M’a rapporté chose sauvaige

Que je n'ay point acoustumee.

En françoys la m’a translatee,

Comme tressouffisant et saige,

Le trucheman de ma pensee.

Quant mon cueur l'a bien escoutee,

Il lui a dit: Vous faittes raige,

Oncques mais n’ouÿ tel messaige.

Venez vous d'estrange contree,

Le trucheman de ma pensee?

(R179: 1-12)

The interpreter of my thought, / Who speaks many a different language, / Reported something wild to me / To which I am not accustomed. / He translated it for me into French, / Being most competent and wise, / The interpreter of my thought. / When my heart heard it well (i.e. the thought) / He (i.e. the heart) said to him (i.e. to the interpreter): You are mad / Never before have I heard such a message. / Do you come from a different land, / Interpreter of my thought?

The poem at once invites and frustrates a narrative reading. We are told that the interpreter of the speaker's thought, who speaks many divers languages, brings the speaker news of something sauvaige with which the speaker, in a rather roundabout phrase, claims to be unaccustomed. The interpreter translates the matter into French and is accused by the speaker's heart: vous faittes raige. The heart has never heard anything like it: 'Have you been in an estrange land?' he asks the interpreter. Charles's depiction of the processes of thought is typically intricate here, but the semantic breadth of divers, sauvaige, faire raige and estrange complicates matters further: divers could mean 'bizarre' or 'unpleasant' as well as just 'different'; sauvaige might be translated as 'wild,' 'primitive', 'strange', 'unpleasant', or 'marvellous'; the phrase 
vous faittes raige might indicate that the heart thinks that the interpreter is acting madly, or that he is trying to show off; estrange might mean 'different', 'unusual', or perhaps 'hostile.' ${ }^{9}$ All this makes the tone of the poem difficult to gauge. What are we to make of the speaker's expression of pique at the opening of the poem? And what of the heart's outrage, voiced at its close?

The language in which the speaker of rondel 179 thinks is not clear, but the translation or re-translation of those thoughts into French is not sufficient to make them comprehensible. Even in French, they strike the heart as outlandish (it is a typically Aurelian move to leave us ignorant of the speaker's reaction to the message). Drawing together some of these points in her brief but suggestive reading of rondel 179, Butterfield highlights the fraught attitude towards French expressed in the text, concluding that its speaker is now a stranger to his own language..$^{10}$ This reading is of a piece with one of the Leitmotive in Butterfield's study, which is the diversity - in all the medieval senses of the term - of both French and English. Charles warrants mention in the context of an examination of this theme, since he is, as Butterfield states, 'perhaps the most riven example of a vernacular subject in English literary history." In a more extended treatment of rondel 179, Hsy develops Butterfield's analysis into a compelling account of what he terms Charles's 'exilic imagination'. ${ }^{12}$ For Hsy, this is an aspect of the poet's psychology that derives from his experiences of imprisonment and second-language acquisition outre-Manche and that is reflected in the tropes of linguistic and territorial estrangement that animate his French and English poetry.13

Both Butterfield and Hsy draw our attention to the ways in which Charles's verse affords him an opportunity to meditate on his relationships to language and place. Viewed in this fashion, rondel 179 might seem to offer an early, personalized reflection on the trauma associated with first-language attrition, that is, on the process observed in linguistics

9 These glosses are translated selectively from definitions given in the Dictionnaire du Moyen Français (henceforth DMF) s. vv. divers, étrange, rage, sauvage. See http://www.atilf.fr/dmf/. See too Godefroy's Complément du dictionnaire de l'ancienne langue française s. v. rage. The online DMF page for rage links to scans of pages from Godefroy's dictionaries.

10 Butterfield, The Familiar Enemy, 307.

11 Butterfield, The Familiar Enemy, 267.

12 Hsy, Trading Tongues, 198.

13 See Hsy, Trading Tongues, 79-87 and 194-209. 
via which mother-tongue facility is lost, for example, in certain migrant situations, or due to the process of ageing. Holinshed's Chronicle famously records that Charles was returned to France 'speaking better English than Frenche. ${ }^{14}$ The reliability of this report is admittedly compromised by its belatedness: the first edition of Holinshed's text appeared in 1557. Nevertheless, the idea manifest in this retrospective record clearly reflects the duke's own depiction of his difficult relationship to language in rondel 179 and elsewhere in his writing. ${ }^{15}$

For both Butterfield and Hsy, Charles is a figure whose life and writing exemplify the complex imbrication of French and English languages, territories and identities over the broad span of the later Middle Ages. What I want to add to their accounts is a sense of how Charles could try to sort through and reorganize these categories to his own advantage. I begin by demonstrating how this might work in the case of rondel 179, which, at least as much as it shows Charles thinking about his linguistic diversity, also shows him performing a particular version of himself for an audience that he desires to please. In what follows, I situate rondel 179 alongside some of the other texts with which it was contemporaneously written into MS fr. 25458 in order to highlight its theatrical, comic and social potential. In so proceeding, I again follow Butterfield, who has done much to illuminate the networked and performative contexts of medieval lyric as well as its trans-lingual potential. ${ }^{16}$ In my reading of rondel 179 , I hope to establish a basic point that I will go on to develop as I move backwards in time through the duke's oeuvre: Charles's poetic self-representations are artfully situated at the intersection of his publicly known biography and his own very fine awareness of the kind of poetry that was required of him in any given situation.

14 Cited from the 1577 text of the Chronicle entry for 1439-1440, edited at The Holingshed Project: http://english.nsms.ox.ac.uk/holinshed/

15 See, for example, the description of linguistic confusion in rondel 26 ('Cueur endormy en pensee'), in which the speaker's tired heart is said to converse in a hopeless mix of languages: 'Tout met en galimafree, / Lombart, Anglois, Alemant, / François, Picart, et Normant. / C'est une chose faee, / Cueur endormy en pensee!' [He puts everything into the stew, / Lombard, English, German, / French, Picard, and Norman. / It's a marvellous thing, / A heart asleep in thought!] (R26: 8-12).

16 In addition to Butterfield's writing on French as the international language of love in The Familiar Enemy, 234-65, see Ardis Butterfield, 'Why Medieval Lyric?', ELH 82 (2015), 319-43. 


\section{Rondel 179 in Manuscript and Performance}

In her analysis of the evolution of MS fr. 25458, Mary-Jo Arn assigns the inscription of rondel 179 to the third stint of its copying, which she dates from the mid-1440s to the mid-1450s. ${ }^{17}$ Viewed alongside the other texts belonging to this and subsequent stints, rondel 179 rapidly takes on a less sombre aspect than that with which I have hitherto endowed it. To begin with, recent work on MS fr. 25458 by Virginie Minet-Mahy and Jean-Claude Mühlethaler has emphasized the fitness of many of Charles's Blois poems for dramatic performance. ${ }^{18}$ The use within these poems of certain deictic markers, of embedded conversations and of implicit or explicit instructions for reading aloud argues in favour of their recital. The clearest evidence that this mode of reading was anticipated by the members of Charles's Blois circle takes the form of a stage direction added next to the text of rondel 250 ('En l'ordre de mariage'). Having opened with the question of whether there is more pleasure or annoyance in matrimony, the text edges perilously - and comically close towards describing its speaker's own marital situation, which, we are left to assume, is unsatisfactory:

Le premier an c'est la rage,

Tant y fait plaisant et douls.

Après ... j’ay la tous,

Cesser me fait de langage

En lordre de mariage.

(R250: 8-12)

The first year it's crazy, / It's so pleasant and sweet. / Afterwards ... I've caught a cough / So I'll have to stop there / As regards the order of matrimony.

17 See Mary-Jo Arn, The Poet's Notebook: The Personal Manuscript of Charles d'Orléans (Paris BnF MS fr. 25458), Texts and Transitions 3 (Turnhout, 2008), 101-26. Arn's study is accompanied by a CD giving a searchable synoptic table of the manuscript. Sorting this table by stint, it is possible to see at a glance to which phase of the book's copying Arn attributes each poem in the book.

18 See Virginie Minet-Mahy and Jean-Claude Mühlethaler, 'De la lecture à la performance: Le "Livre d'Amis" de Charles d'Orléans', in Les Manuscrits médiévaux témoins de lectures, ed. Catherine Croizy-Naquet, Laurence Harf-Lancner and Michelle Szkilnik (Paris, 2015), 175-96. 
On the page in MS fr. 25458 that records this rondel (p. 450), the instruction '[ii.] foiz toussir' [cough twice] has been added to the left of line 10; by following the instruction, a performer of the text can complete the metre of this otherwise deficient verse. In Charles's personal manuscript, rondel 250 is presented as a performance script. ${ }^{19}$

Rondel 179 also seems fit for dramatic recital. It contains direct speech in its final stanza and, as is the case in rondel 250, its performance might be made to turn on a sexual innuendo. Specifically, a performer of the poem might foster the impression that the messaige prompting the heart's shocked speech in lines 9-12 of rondel 179 was some sort of inappropriate erotic proposition passing from the speaker's thought via his interpreter.

Mühlethaler points out Charles's predilection for louche double entendre throughout his later poetry. ${ }^{20}$ Among these texts, another of the duke's Blois productions, chanson 55, further illuminates the performance potential of rondel 179:

Reprenez ce larron souspir

Qui s'est emblé soudainement

Sans congié ou commandement

Hors de la prison de Desir.

Mesdisans l'ont ouÿ partir

Dont ilz tiennent leur parlement.

Reprenez ce larron souspir

Qui sest emblé soudainement.

Se le meschant eust sceu saillir

Sans noyse tout priveement,

N'en peust chaloir, mais sotement

L'a fait; pource l'en fault pugnir.

Reprenez ce larron souspir.

(Ch55: 1-13)

19 MS fr. 25458 has been digitized and may be viewed at https://gallica.bnf. fr. The manuscript has been cropped; the numeral in square brackets reflects Minet-Mahy and Mühlethaler's estimation that two coughs are required in order to complete the line. See 'De la lecture à la performance', 178. Any performance of rondel 250 by the duke at Blois looks likely to have been a memorable event: Charles's third wife, Marie de Clèves (1426-1487), was an active participant in the poetic life of her husband's court, contributing two rondels to his book (R195 and R242).

20 See Mühlethaler, Charles d'Orléans, e.g., 89-103. 
Take back this rascally sigh / That has suddenly escaped / Without leave or instruction / From the prison of Desire. / Slanderers have heard it depart / And are discoursing on it. / Take back this rascally sigh / That has suddenly escaped. / If the rascal could have done it / Without making a din, in private, / It would not have mattered, but foolishly / He has acted; so he must be punished! / Take back this rascally sigh.

Like the speaker of rondel 179, the speaker of chanson 55 expresses indignation at some kind of infraction. In the chanson, however, the perceived breach is clearly externalized and its eroticism is patent: a sigh between lovers has escaped within the earshot of slanderers. Given the nature of the scene, in their edition of the Blois poetry, Minet-Mahy and Mühlethaler suggest that Charles assumes a woman's voice here. ${ }^{21} \mathrm{I}$ wonder whether we would do better to imagine the prince in drag. The difficulties inherent in attempts to gauge the tone of the speaker's and the heart's professions of indignation in rondel 179 were alluded to above. In chanson 55, we are more clearly in pearl-clutching territory. The displeasure expressed in this text is made comic through the elevated and pleonastic language used to describe the sigh's unfortunate issue 'without leave or instruction'; the subsequent allusion to the chatter of the gossips in their 'parlement' is another aspect of the speaker's risible grandeur. Then comes the verb saillir, whose polyvalence further undercuts the speaker's expression of outrage. Its possible translations range from the anodyne 'depart' to 'gush forth' and, equally explicitly, 'serve', where the Modern English word has the sense given in the OED s. v. serve, v. 1 (52) 'of a male animal: to cover (the female); esp. of stallions, bulls, etc. kept and hired out for the purpose..22 In the final stanza, the pretence of offence is abandoned as the speaker looks forward to more illicit action. If the 'souspir' had been a quiet one (is the speaker still talking about a sigh here?), it might have been pardoned; since it has acted foolishly - and noisily - it must be punished!

It is possible, I think, to hear the falsetto tones of chanson 55 in rondel 179. Reading across the Blois poems, we quickly glean a sense of the pleasure that Charles takes in such acts of impersonation. In one rondel he might elect to elaborate upon the self-portrait that he had sketched

21 See Le Livre d’amis: poésies à la cour de Blois (1440-1465), ed. Virginie Minet-Mahy and Jean-Claude Mühlethaler (Paris, 2010), 22.

22 Compare DMF s. v. saillir. My translation of saillir as 'do it' is an attempt to replicate the punning on the term in the poem. 
in the Songe en complainte, in which he presents himself as an ageing and cynical observer of amorous adventure. ${ }^{23}$ In another, he could present himself as a man sick with love (R59: 'Plus penser que dire'); a love-doctor (B142: 'Bon regime sanitatis'); a prince assailed by interested flatterers (R139: 'Procul a nobis'); a confidant (Co6: 'Fredet, jay receu vostre lectre'); or as a seedy older man whose senile desires might even colour his public addresses to his sister-in-law (R270: 'A ce jour de Saint Valentin / Puis qu'estes mon per'). When among his courtiers at Blois, Charles seems to have harboured a desire to experiment, as Jane H. M. Taylor puts it, with the 'poetic and dialogic potential of miscellaneous identities.. ${ }^{24}$

Taylor has done more perhaps than any other reader of Charles's poetry to illuminate the playful and social nature of his Blois verse as well as the communal aspect of its production and consumption. ${ }^{25}$ In particular, her work has shown how Charles's household was an environment in which motifs, openings, refrains and key words were passed among poets who wrote with a view to inclusion in MS fr. 25458. In demonstration of this point, Taylor traces the development of the idea of thought's interpreter that is at the heart of rondel $179 .{ }^{26}$ Its trajectories neatly illuminate the generative potential of such a conceit in the poetic atmosphere at Blois as well as the ways in which writing poetry at Charles's court allowed the duke and his courtiers to confirm their interpersonal relationships.

Taylor focuses on two sequences of poems, the first of which marks what, in my current perspective, might seem like a false start. It begins with a poem by a mysterious contributor to MS fr. 25458 who is identified only as 'Fredet' in the rubrics. ${ }^{27}$ In this poem (R228: 'Le truchement de ma pensee / Ceste saint Valentin'), Fredet sends the truchement of his thought to Love one Valentine's Day with the request that his love pains might be relieved and Love returns the truchement to Fredet with a message of acquiescence. The truchment de ma pensee is not the main

23 On Charles's poetic rendition of the ageing process, see further Ad Putter, 'Personifications of Old Age in Medieval Poetry: Charles d'Orléans and William Langland', Review of English Studies 63 (2011), 388-409.

24 See Jane H. M. Taylor, The Making of Poetry: Late-Medieval French Poetic Anthologies, Texts and Transitions 1 (Turnhout, 2007), 92.

25 See Taylor, The Making of Poetry, 83-145 and 147-227.

26 See Taylor, The Making of Poetry, 116-28.

27 On the contributors to MS fr. 25458 besides Charles, see the index in Poetry of Charles d'Orléans, ed. Fox and Arn, 829-41. 
idea in Fredet's poem that is developed in the chain of rondels to which it gives rise. Simonnet Caillau, another frequent contributor to the book, responds to Fredet's rondel with a poem listing in fantastical detail the possible medical cures for the pains from which Fredet has claimed to suffer (R229: 'Pour bref tels maulx d'Amours guerir'), and this poem in turn generates three other medicalizing treatments of love: one by Jehan de Lorraine (R231: 'Pour brief du mal d'amer guerir') and two by Charles (R230: 'Les malades cueurs amoureux' and R232: 'Pour tous voz maulx d'amours guerir').

The other sequence of poems that Taylor addresses makes more extensive use of the truchement motif, beginning with two poems by Charles. In the first, R178 ('Le trucheman de ma pensee / Qui est venu devers mon cueur'), the trucheman (as Charles apparently spelled the word) appears, as he does in Fredet's text, looking more like an envoy than an interpreter. ${ }^{28}$ Where in rondel 178 the trucheman traffics letters between Reconfort and the speaker's heart, in rondel 179, as we have seen, the trucheman takes on his role as the translator of the speaker's thought. In rondel 181, the phrase gets one last outing. In this poem, the count of Clermont assumes the voice of a speaker claiming to be the originator of the pensee received by the trucheman in rondel 179:

Le trucheman de ma pensee,

Qui de long temps est commancee,

Va devers vous pour exposer

Ce que de bouche proposer

N'oze, craignant d'estre tancee.

(R181: 1-5)

The interpreter of my thought, / Who (i.e. thought) has been at him (i.e. the interpreter) for ages, / Goes to you in order to expose / That which to propose by mouth / I dare not (or: it, i.e. thought, dares not), fearing to be rebuked.

The provocation that was internalized in rondel 179 is thus externalized in rondel 181. The count goes on to claim that the trucheman has nothing to transmit on account of which his reception ought to be hindered and closes with a request that the he might be rewarded for his service. Taylor assumes that the speaker of the poem is a woman, but the grammatical 
evidence is equivocal. ${ }^{29}$ Given the gender-bending that I have argued characterizes chanson 55 and, perhaps, rondel 179, it is equally possible to imagine this rondel constituting a self-consciously butch response to a high-camp performance of the previous, generative text.. ${ }^{30}$

These brief summaries indicate the ease and productiveness with which motifs and ideas could be passed among the members of Charles's coterie. The nature of the collaborative, citational mode of composition pursued by the contributors to MS fr. 25458 frustrates any attempt definitively to determine the chronology of their texts. I have presented the two truchement sequences in the order in which Taylor discusses them, following Champion's edition of the poems, which reflects his understanding of the order in which the texts were written..$^{31}$ In their new edition of MS fr. 25458, Fox and Arn swap the larger sequences of rondels to which rondels 228-32 and 178-81 belong, presenting rondels $178-81$ as the earlier productions. Their reasoning for this rearrangement is plausible, but not definitive. ${ }^{32}$ This leaves us with two possibilities for the development of the truchement motif: either

29 See Taylor, The Making of Poetry, 128. The second - $e$ on tancee in line 5 might reflect the gender of the imagined speaker of the text, or of pensee in line 1 . This second reading of the past participle informs the Modern French translation of the poem offered in Le livre d'amis, ed. Minet-Mahy and Mühlethaler, 385. The text of the poem offers a range of performance possibilities: the feminine -ee endings here and elsewhere in the rondel would not have been be heard by a live audience as distinct from their masculine equivalents in $-e$.

30 The comic expressions of desire shared between men that I have been tracing here might recall the classic study of male same-sex desire in medieval French literary contexts by Simon Gaunt, 'Bel Acueil and the Improper Allegory of the Romance of the Rose, New Medieval Literatures 2 (1998), 65-93. In his most recent work on Charles, Hsy brings twenty-first-century gender theory to bear on the poet's bilingual writing. See Jonathan Hsy, 'Linguistic Entrapment: Interlanguage, Bivernacularity, and Life Across Tongues', postmedieval 9 (2018), 196-208.

31 See Charles d'Orléans: Poésies, ed. Pierre Champion, Classiques français du Moyen Âge 34 and 56, 2 vols (Paris, 1923, 1927).

32 See Poetry of Charles d'Orléans, ed. Fox and Arn, xxv-xxvi. Fox and Arn argue that, over time, Charles's circle at Blois is likely to have grown and that the duke's autograph contributions to his book are likely to have fallen off. Their reordering of the rondels reflects this conception of life at Blois and of the duke's autograph work. It is also possible, however, that both communal poetry at Blois and Charles's direct involvement in the writing of his book progressed less consistently, ebbing and flowing. The truchement motif, after all, gets two apparently distinct outings. 
(following Champion's chronology) the phrase was found by Fredet and after a period of incubation picked up again by Charles and the count of Clermont, or (following Fox and Arn's chronology) Charles found the motif and developed it in a fashion that prompted the count to take it up, before it was picked up again, after the incubatory period, by Fredet, who used it to initiate another poetic chain on a different topic, in which the duke and other members of his circle also came to participate.

It is significant that, in rondel 179 , Charles personalizes the truchement motif by referring to his own polyglot identity. This is an aspect of his biography with which we can assume his coterie was thoroughly familiar; here we can see him turning it into poetry.33 Charles's description of his linguistic befuddlement in rondel 179 corresponds to the requirements of the situation for which it was written. It allows him to craft a performance piece that appeals to the taste for self-consciously allusive and occasionally salacious lyric that is in evidence elsewhere in the total corpus of the Blois circle; it allows him to participate in a kind of gender-play in which his poetic peers were also engaged; and it shows him either originating or picking up again a poetic cue of the kind that generated so much of the Blois verse. While the content of the poem is not insignificant, the rondel is also meaningful for what Taylor calls its 'meta-communicative' function - that is, for its capacity to collect and manipulate a set of signals and clues determining social relationships. ${ }^{34}$

\section{IN ENGLAND}

The conditions under which the duke wrote his prison poetry in England differed broadly from those prevailing at Blois and the relationships that he might imagine developing with his audiences were tenser. The ways in which the duke represented his exiled identity in his prison poetry were adapted to suit these parameters and, at the same time, he would seem to have exerted more deliberate control over the circulation of his work.

33 In this connection, see too Taylor's tracing of the prison metaphor as this crops up across the rondels composed at Blois in The Making of Poetry, 133-45. 34 See Taylor, The Making of Poetry, 8-9. 


\section{The French Prison Poetry: A Discrepancy}

At first glance, Charles's French prison poetry presents a discrepancy. Alongside poems that delicately allude to the duke's incarceration, there are others that address it more directly, or in which the poet shows himself working behind the scenes in order to organize his release. ${ }^{35}$ Alongside a series of poems evoking the duke's 'prison de Desplaisance' [prison of Displeasure] (B25: 'Mon cueur a envoyé querir', refrain), or representing him on the 'dur lit d'Ennuieuse Pensee' [the hard bed of Painful Thought] (B66: 'Le beau souleil, le jour saint Valentin', refrain), or in the 'fers de Destresse' [the irons of Distress] (Co1: 'Amour, ne vous veuille desplaire', line 51), that is, we also have the poems appearing in the manuscript under the rubric 'Balades de plusieurs propos' (MS fr. 25458, p. 203). These ballades include a series of poems that endow Charles's imprisonment with a more personalized sense of pathos. In them, the poet regrets the youth that he has spent in captivity, describing himself as having been 'mis pour meurir ou feurre de prison' [put to ripen on prison straw] (B120: 'Je fu en fleur ou temps passé d'enfance', refrain); or he imagines Soing and Ennuy triumphantly asserting their mastery over him and pointedly locates the arena of his suffering 'ou royaume d'Angleterre' [in the kingdom of England] (B121: 'Cueur, trop es plain de folie, refrain); or he writes to correct rumours back home that he is already dead, asserting 'qu'encore est vive la souris' [that the mouse is still alive] (B122: 'Nouvelles ont couru en France', refrain). The 'balades de plusieurs propos' also include two sequences of texts addressed to historical individuals. Since these sequences show Charles in a different light to the rest of the prison poetry, and since they have often been overlooked, I want to focus on them more closely.

In the first of these sequences, Charles writes to his fellow captive, Jean de Bourbon; like Charles, Jean was taken at Agincourt. Until his death in London in 1434, Jean was allowed to journey to France on several occasions in order to try to raise his ransom and to speed the arrangements for the release of Charles and the other Agincourt

35 On this point, see Patrizio Tucci, “Adevinez, je vous en prye!” Lécriture allusive chez Charles d'Orléans', in Stromates: du XIVe siècle au symbolisme (Padua, 2004), 5-35 (14-17). When writing of Charles's 'prison poetry', I refer to the bodies of French and English verse compiled in MSS fr. 25458 and Harley 682 just prior to his release. For a chart identifying the poetry inscribed in MS fr. 25458 by this point, see Arn, The Poet's Notebook, 187. 
prisoners. ${ }^{36}$ In ballade 123 ('Puis qu'ainsi est que vous alez en France'), Charles pictures himself writing to Jean just prior to one of these trips. Charles asks his fellow prisoner to recommend him to his lady and to remind her of the pains that he is suffering in England. At the same time, he insists on keeping her identity out of the poem; Jean will know whom he means. The ballade's refrain emphasizes the duke's teasing reticence: 'il ne fault ja que plus je vous en die' [I need not ever tell you any more of this]. In the second Bourbon poem (B124: 'Mon gracieux cousin, duc de Bourbon'), Charles writes to Jean in France, asking him to send him news in the form of a poem and expressing in an optimistic refrain his conviction that an upturn in their situation will soon be brought about 'par bonne paix que brief Dieu nous envoye' [through good peace - may God send it to us soon]. Then, in the final poem in this sequence, we meet a further shift in tone:

Mon chier cousin, de bon cueur vous mercie

Des blans connins que vous mavez donnez,

Et oultre plus, pour vray vous certiffie,

Quant aux connins que dittes quay amez,

Ilz sont pour moy, plusieurs ans a passez,

Mis en oubly; aussi mon instrument

Qui les servoit a fait son testament

Et est retrait et devenu hermite.

Il dort tousjours, a parler vrayement,

Comme celui qui en riens ne prouffite.

(B125: 1-10)

My dear cousin, I thank you wholeheartedly / For the white rabbits that you have given me, / Moreover besides, certifying to you as true that, / As for the rabbits that you say I have loved, / They were for me, many years ago / Forgotten; also my instrument / Which used to serve them, has made its testament / And is retired and has become a hermit. / He sleeps constantly, to speak truthfully, / Like he who finds profit in nothing.

If the ballade was prompted by the gift of some real rabbits, it is clear by its fourth line that a different kind of connin is at issue: the word is routinely used in less courtly Middle French to refer to the vagina (see

36 On Jean de Bourbon, see the note in Poetry of Charles d'Orléans, ed. Fox and Arn, 884 . 
DMF s. v. connin; cf. OED s. v. cunny). Charles claims long ago to have given up on this second kind of rabbit: the 'instrument' he used to serve them with is now retired (literally: retracted) and has become a sleepy hermit. In the remainder of the poem, Charles counsels a switch from chatting about sexual excess to its alimentary equivalent (which seems, it must be said, to contain a rather revolting portion of its lascivious other):

Parler vault mieulx, pour faire chiere lie,

De bons morceaulx et de frians pastez,

Mais qu'ilz soient tout chaudement tastez!

Pour le present, c'est bon esbatement,

Et quon ait vin pour nettier la dent.

En char crue mon cueur ne se delitte.

(B125: 13-18)

It's better to talk, to make ourselves merry, / About flavoursome morsels and tasty foods, / So long as they're tried hot! / For now, it's good game, / And let us have wine to wash it all down. / My heart takes no delight in raw flesh.

In the envoy appended to the ballade, Charles concludes that he and Jean should leave loving to the young: 'Vieulx soudoiers avecques jeune gent / Ne sont prisiez la valeur d'une mitte' [old soldiers next to young folk / Are not worth a mite] (B125: 31-32). In the Bourbon poems, then, the mode of address adopted allows the poet to show himself in a series of new guises. As he appears there, the duke is actively engaged in the game of love (and to a French lady); he is confident of an upturn in his situation; and he is not so downcast by his imprisonment that he is incapable of turning a smutty ballade on the topic of senile love. ${ }^{37}$

The second of the sequences of 'balades de plusieurs propos' addressed to a historical person sees Charles engaged in poetic correspondence with Philippe de Bourgogne. The historical background to this exchange

37 For the argument that Jean de Bourbon is adopted as an addressee precisely to allow Charles to try on these roles (we never hear Jean's replies), see Estelle Doudet, 'Orléans, Bourbon et Bourgogne: Politique de l'échange dans les Ballades de Charles d'Orléans', in Lectures de Charles d'Orléans: les ballades, ed. Denis Hüe (Rennes, 2010), 125-39 (129-32). Doudet's essay also contains much useful commentary on the exchange between Philippe de Bourgogne and Charles, on which I draw below. 
has been filled in by Ann Tukey Harrison, who points out that while the two men had been on opposing sides of the French civil wars since the murder of Charles's father, Louis, on the order of Philippe's father, Jean, in 1407, their rapprochement was made politic by the new peace treaty between France and Burgundy that was ratified at Arras in $1435 .^{38}$ Philippe's relations with the French king, Charles VII, remained strained, and might be improved through Charles's intercession; for his part, Charles saw Philippe as the potential agent of his long-awaited release. The ballades between Philippe and Charles show the two men negotiating their relationship in language which, in contrast with the other prison poetry compiled in MS fr. 25458 , tends unusually towards the specific. It is for this reason that I want to cite them at some length.

The sequence begins with a ballade written by Charles, apparently at Calais, in which Charles asks Philippe for his news and expresses his desire for a closer relationship with him (B127: 'Puis que je suis vostre voisin'). Charles prays for peace, which he claims will enrich all concerned - 'Elle departira butin, / De grans biens a tous largement' [it will share out booty / of great benefit broadly to all] (B127: 19-20) - and he closes with an envoy that locates his addressee nearby in the Pas-deCalais and that reaffirms his loyalty to him:

Va, ma ballade, prestement

A Saint Omer, moustrant comment

Tu vas pour moy ramentevoir

Au duc a qui suis loyaument,

Et tout a son commandement,

S'il en estoit a mon vouloir!

(B127: 25-30)

Go, my ballade, swiftly / To Saint-Omer, showing how / You go in order to remember me / To the duke, whose man I am, loyally, / And would be entirely at his instruction, / If it were according to my desire.

In his response (B128: 'S'il estoit a mon vouloir'), Philippe takes Charles's refrain as his incipit, asserting that if it were to go according to his desire, Charles would be out of prison 'sans attargier' [without delay] (B128:

38 Ann Tukey Harrison, 'Orleans and Burgundy: The Literary Relationship', Stanford French Review 4 (1980), 475-84. See too the note in Poetry of Charles d'Orléans, ed. Fox and Arn, 885. 
5). Philippe goes on pointedly to emphasize Charles's capacities as a peacemaker:

Se tel don povez recevoir

Par la grace Dieu, de legier

Pourrés tel a paix esmouvoir

Qui la desire eslongier.

Nul contre n'osera songier.

(B128: 9-13)

If you can receive such a gift (i.e. the gift of liberation) / By the grace of God, with ease / You will be able to move to peace / Whoever might desire to thrust it aside. / No one will dare to think otherwise.

After all, it is from Charles's moral authority that Philippe hopes to benefit when the duke is finally released.

Philippe closes with an exhortation to Charles that he should get on with their work so that they can both take refuge in peace. In his envoy, he announces Charles's release as a condition of this outcome:

Or pensons de vous allegier

De prison, pour tout engagier,

Se n'avons paix et unïon,

Et du tout my vueil obligier,

En ceste presente saison.

(B128: 25-29)

Now let us plan to relieve you / From prison, to engage all in this, / Without which we shall have neither peace nor union, / And entirely I want to devote myself to this, / In this present season.

In the next pair of ballades, Charles presents himself writing in haste, only to thank Philippe for his poem and asserting that he is beholden to Burgundy entirely: 'De cueur, de corps et de puissance' [in heart, body and might] (B129: 'Pour le haste de mon passage', refrain). When he has more time, he promises to send Philippe a messenger. Effectively, he announces his intention to spy on his captors for Philippe:

Je vous envoyeray message,

Se Dieu plaist, briefment sans tarder, 
Loyal, secret et assez sage,

Pour bien a plain vous infourmer

De tout ce que pourray trouver

Sur ce que savoir desires.

(B129: 12-17)

I shall send you a messenger / If it pleases God, shortly and without delay, / A loyal, discreet, and rather wise one, / In order to inform you well and fully / About everything that I can find out / Regarding what you desire to know.

Philippe should work similarly for Charles among the French. Charles dedicates himself to Philippe using the courtly language of the gift of the heart: 'vous laisse mon cueur en gage' [I leave you my heart as surety] (B129: 25). He then commends himself to Philippe's wife, whom he calls 'ma cousine' (B129: 28), and closes with an envoy that at once challenges Philippe to produce a result and announces his allegiance to Burgundy with new vigour: 'Tout Bourgongnon sui vrayement' [I am entirely Burgundian, truly], he concludes, 'De cueur, de corps et de puissance' (B129: 38-39).

In his second reply (B130: 'De cueur, de corps et de puissance'), Philippe again picks up Charles's refrain as his incipit, but his new refrain suggests the potential fragility of the relationship between the two men. Throughout his reply, Philippe repeatedly affirms his loyalty to Charles's cause 'quoy que nul die ne deppose' [whatever people might say or claim]. Philippe emphasizes the terrible situation in which the house of France finds itself, promising to fill in the details at a later date: 'vous saurés tout, quoy et comment' [you will be informed of everything, all the ins and outs] (B130: 14). He reasserts his belief that Charles's delivery is a precondition of peace - 'sans ce,' he writes 'je n'ay esperance' [without this, I have no hope] (B130: 21) - but, finally, offers little news of substance to embolden Charles.

The story is completed by two ballades by Charles, neither of which is matched with a response from Philippe. In the first (B131: 'Des nouvelles d'Albion'), Charles announces his temporary release from prison in order to seek both peace and his ransom; Charles hopes for help with the latter from Philippe, who, Charles knows, also desires the former. Charles's deployment of the pronoun 'la' in line 14 of the ballade encapsulates the interrelation of these two things, as Charles sees it, as if to drive the point home to Philippe that now is the time to pay up: 
Je doy estre une saison

Eslargi pour pourchasser

La paix, aussi ma raençon.

Se je puis seurté trouver

Pour aler et retourner,

Il fault qu'en haste la quiere,

Se je vueil brief achever

En bons termes ma matiere.

(B131: 9-16)

I am for a season to be / Set free in order to pursue / Peace, and also my ransom. / If I can secure safe conduct / To go and to come back, / I must seek it (i.e. peace/ransom) in haste, / If I hope shortly to conclude / My matter in good terms.

Charles concludes by asking Philippe to make good on his promise to help him - 'A ce cop veuilliez m'aydier' [please help me to bring this off] (B131: 18) - and this idea is picked up and developed in the last ballade in the sequence, written just before Charles' repatriation (B135: 'Beau frere, je vous remercie'). Here Charles claims that his release is stalled only for want of funds; he is ready to commit himself even to a Lombard merchant, provided his ransom is collected. In the envoy to the text, the duke is direct about the loyalty that he promises to whomever might save him:

Qui mostera de ce tourment,

Il machetera plainement

A tousjours mes, a heritage.

(B135: 25-27)

Whoever removes me from this torment / He will buy me completely / For ever, as an inheritance.

Like the Bourbon poems, the texts exchanged between Charles and Philippe present an image of Charles that differs markedly from that developed in the love story framed by the introductory narrative and the Songe en complainte. ${ }^{39}$ Within the bounds of these opening and closing

39 In one last poem written into MS fr. 25458 just after Charles's release, the duke apologizes to Philippe for not publicly acknowledging their friendship while he is among Philippe's enemies (B136: 'Pour ce que je suis a presant'). 
movements, which narrate the poet's induction into and withdrawal from Love's service, references to Charles's incarceration of the kind cited at the opening of this section partake of the topos of 'Love's prison', a popular medieval conceit that deliberately blurs the line between fact and fiction. ${ }^{\circ}$ By contrast, the Bourbon poems show a more lively, optimistic personality, and the Burgundy poems show Charles as quite the political animal. In the sequence of poems that he exchanges with Philippe, Charles presents himself as a willing spy, a canny negotiator and, finally, as a man whose loyalties are up for sale. These poems directly contradict any claims of trustworthiness or loyalty to the English cause that Charles might make to his captors regarding the conditions of his release. These conditions, when they were finalized, stipulated, for example, that if Charles was unsuccessful in brokering a peace between France and England (as he indeed turned out to be) he would voluntarily return to his English prison. ${ }^{41}$ The nature of the French prison poetry suggests that Charles would have watched over its circulation closely in England. The surviving records for the transmission of this portion of Charles's oeuvre corroborate this assumption.

\section{The French Prison Poetry: Manuscript Transmission}

While work on Charles's personal manuscript has advanced apace since Champion's identification of the poet's autograph work in the book, scholarship on the other manuscripts transmitting Charles's French poetry remains in its infancy..$^{42}$ Nevertheless, working from the reports of Charles's literary peers, from the available inventory records of the libraries of Charles and his readers, and from the manuscript record itself, it is possible to piece together a suggestive picture of the transmission of Charles's French poetry dating back to c.1440. To begin with, mention

40 On this conceit, see the comments on Jean Froissart's Prison amoureuse (1372-1373) in Laurence de Looze, Pseudo-Autobiography in the Fourteenth Century (Gainesville, 1997), 114-28.

41 Documents dated to 2 July 1440 outline the conditions of Charles's release. They are reproduced in 'Rymer's Foedera with Syllabus: July-September 1440', in Rymer's Foedera, vol. 10, ed. Thomas Rymer (London, 1739-45), 776-803. This resource has been digitized and may be viewed at British History Online: http:// www.british-history.ac.uk/rymer-foedera/

42 For the identification of Charles's hand in MS fr. 25458, see Pierre Champion, Le manuscrit autographe des poésies de Charles d'Orléans, Bibliothèque du XVe siècle 3 (Paris, 1907). 
of Charles's French work by Martin le Franc in his Champion des Dames (1441-1442), addressed to Philippe de Bourgogne, makes clear the circulation of at least one anthology of Charles's poetry about this time. When in the third book of that work Martin presents Charles as an authority on love conduct, he directs his readership to seek out the duke's book:

Se tu ne me crois, si enquier

Le livre qu'il fit en Inglant:

La pert se les dames eut quier

Et se Venus l'ala senglant. ${ }^{43}$

If you do not believe me, then seek out / The book that he made in England: / There it is made plain if he held women dear / And if Venus kept him bound.

As Georges Doutrepont pointed out, ${ }^{44}$ the book that Charles 'fit en Inglant' probably corresponds to the item inventoried among Philippe's books at Bruges in 1467 as

ung petit livret en parchemin couvert de couverture de parchemin, intitulé au dos: C'est le livre de monsegneur d'Orléans, escript en rime à deux coulombes; quemenchant ou second feuillet, Si alâmes en ce point jusques au lieu, et le dernier feuillet, ballade de me dame, armoyé ou premier feuillet en bas, des armes de monseigneur d'Orléans. ${ }^{45}$

a little book in parchment covered with a cover of parchment, entitled on the back: This is the book of monsegneur d'Orléans, written in rhyme in two columns; starting on the second leaf, So, in that fashion we went as far as the place, and [reading on] the last leaf, ballade of my lady, marked on the first leaf at the bottom with the arms of monseigneur d'Orléans.

43 Martin le France, Le Champion des Dames, ed. Robert Deschaux, Classiques français du Moyen Âge 127-131, 5 vols (Paris, 1999), Book 3, lines 11913-16.

44 See Georges Doutrepont, La Littérature française à la cour des ducs de Bourgogne (Paris, 1909), 379.

45 Cited from Joseph Barrois, Bibliothèque protypographique ou Librairies des fils du roi Jean, Charles V, Jean de Berri, Philippe de Bourgogne et les siens (Paris, 1830), item 1400. It would seem that the beginning of the book had suffered damage by the time it was inventoried. 'Si alasmes en ce point jusqu'au lieu' is line 155 of the introductory narrative giving the story of Charles's enrolment into Love's service. 
It seems likely that Martin became acquainted with Charles's prison poetry so early because he read it in this copy, which we can imagine Charles sending to Philippe about the time of his release either as a spur to action or as thanks for Philippe's work towards his liberation. ${ }^{46}$

As Champion recognized, the book seen by Martin le Franc belongs to a family of anthologies collecting the duke's prison writing. ${ }^{47}$ Two of these are known only as entries in other book lists. Among the list of books that Charles brought back to Blois with him after his release there is mention of an apparently independent collection of his ballades, 'Le Livre des Balades de monseigneur, a ung fermouer a ses arms' [The Book of Ballades by Monseigneur, having a clasp marked with his arms].$^{48}$ In a 1498 inventory of the library of the Chateau de Chambéry, we also find listed a book containing the duke's prison verse: 'ung livre de papier moyen escript a la main en vers tractant de monseigneur d'Orleans estant en prison en Angleterre, commençant en la grosse lectre: Sensuyt, couvert de papier coullé' [a book of middling paper written by hand in verse about monseigneur d'Orléans being (i.e. when he was) in prison in England, beginning with the large incipit: Here follows, covered with moulded paper]. ${ }^{49}$

Two extant manuscripts also advertise themselves as collections of the duke's prison poetry. Paris, Bibliothèque de l'Arsenal, MS 2070 announces its collection of the duke's verses as

le livre que fist monseigneur d'Orleans lui estant prisonnier en Angleterre ou quel y a dedans plusieurs belles ballades et rondeaulx envoiez a madame sa femme et la responce d'iceulx moult plaisant a lire (fol. 1r).

46 On the politics of this gesture, see further Gérard Gros, 'Le Livre du prince et le clerc: édition, diffusion et reception d'une ouvre (Martin le Franc lecteur de Charles d'Orléans)', Travaux de Littérature 14 (2001), 43-60.

47 See Pierre Champion, La Librairie de Charles d'Orléans avec un album de fac-similés, Bibliothèque du XVe siècle 11, 2 vols (Paris, 1910), 1:lx.

48 Cited from the transcription of this list in Gilbert Ouy, La Librairie des frères captifs: les manuscrits de Charles d'Orléans et Jean d'Angoulême, Texte, Codex \& Contexte 4 (Turnhout, 2007), 48. Champion thought that this manuscript would later be incorporated into MS fr. 25458 but Ouy and others have argued that MS fr. 25458 in its early form is described elsewhere in the Blois book list as 'plusieurs quaiers de parchemin nouvellement escrips et enluminés apportés d'Angleterre qui ne sont point reliés' [several quires of parchment, recently written and illuminated, brought from England, which are not bound] (Librairie des frères captifs, 9).

49 Cited from Arthur Piaget, 'Jean de Garencières', Romania 87 (1893), 422-81 (427 n. 1). 
The book that monseigneur d'Orleans made, he being a prisoner in England, in which there are within several fine ballades and rondels sent to madame his wife and the response to the same which is very pleasurable to read.

Paris, Bibliothèque nationale de France, MS fr. 19139 likewise presents its selection of Charles's poetry as 'le livre que Monseigneur Charles duc d'Orleans a faict estant prisonnier en Angleterre' (fol. 1r) [the book that Monseigneur Charles, duke of Orleans made being a prisoner in England].$^{50}$ Finally, to these books compiling Charles's carceral verse in French, we can add two further manuscripts: London, British Library, MSS Royal 16 F. ii and Lansdowne 380. Although the Royal manuscript does not explicitly advertise itself as an anthology of the duke's prison poetry, it transmits only texts written prior to Charles's release and reminds its reader of the poet's work in captivity in its famous illustration showing Charles writing in the Tower of London (fol. 73r)..$^{51}$ Lansdowne 380 is an altogether more modest book but one that also only contains poems by Charles that were written prior to his release. ${ }^{52}$

With the exception of the mention of the 'Livre des Balades de monseigneur' in Charles's Blois book list, both the inventory records and the extant manuscripts postdate the $144 \mathrm{O}$ os. It is not possible to reconstruct the history of their copying with certainty. It seems likely, however, that they are representative of a kind of book of the duke's poetry whose first exemplars were codices like that in which Martin le Franc saw Charles's work. ${ }^{53}$ Given the evidence that these manuscripts provide for the early

50 The incipits to MSS Arsenal 2070 and fr. 19139 are cited from Charles d'Orléans Poésies, ed. Champion, ix- $\mathrm{x}$, where the other contents of these manuscripts are listed. The explicits to these collections, also cited by Champion, likewise clearly identify them as collections of the duke's prison poetry.

51 London, British Library, MS Royal 16 F. ii. has been digitized and may be viewed at https://www.bl.uk/manuscripts/. I have checked its contents via this digital facsimile.

52 For a detailed table listing the contents of London, British Library, MS Lansdowne 380, see Kathleen Sewright, 'An Introduction to British Library MS Lansdowne 380', Notes 65 (2009), 633-736 (675-736). Sewright's work is discussed at greater length below.

53 Since the illustrators of the Royal manuscript are Flemish, Champion suggested that the Royal manuscript might derive from the copy of the duke's prison poetry in Philippe de Bourgogne's library. See Charles d'Orléans: Poésies, ed. Champion, xi. More recently, Janet Backhouse has tentatively argued that the 
circulation of Charles's ballades, it is important to note that they bear witness to two different modes of collecting the duke's work: one transmitting the more topical poetry among the 'balades de plusieurs propos' and one omitting it. Thus the poems identified above as presenting a more personalized version of the duke's imprisonment (B120-22) are included in the Royal manuscript, as are two of the Bourbon poems (B123, B125) and the poetic exchange between Charles and Philippe de Bourgogne (B127-31).54 These poems are not present in the anthology of the duke's prison verse in MS fr. 19139.5 In her groundbreaking article on Lansdowne 380, Kathleen Sewright shows that the collection of Charles's poetry transmitted in this anthology also omits the duke's political verses. ${ }^{56}$ She argues, moreover, that this manuscript can be identified as a native English production. ${ }^{57}$

The absence of the political verse from Harley 682, which I go on to discuss below, compounds the likelihood that the depoliticized version of the duke's corpus represented in MS fr. 19139 and Lansdowne 380 was initially directed to an English audience, whereas the politicized corpus was sent into the Continent, perhaps first to Philippe de Bourgogne, to whom Charles desired to demonstrate his usefulness as an able ally. $^{58}$ We know from Arn's and Coldiron's work, which I cited in the opening paragraph of this chapter, that Charles personally oversaw the production of some of the extant books of his verse. It makes sense, I think, to attribute responsibility for the divergent transmission history of the prison texts to the duke himself. Finally, since the contents of

Royal book found its origins in Calais. See Janet Backhouse, 'Charles of Orléans Illuminated', in Charles d'Orléans in England, ed. Arn, 145-63 (161-62).

54 The order in which these poems appears in the Royal manuscript seems brouillé, as Champion has it, but Fox makes a good case for the reasoned reorganization at least of the book's first forty-four Aurelian items, which he edits. See Charles d'Orléans: choix de poésies, ed. John Fox (Exeter, 1973), ix-xvi. 55 MS fr. 19139 has been digitized and may be viewed at https://gallica.bnf.fr. I have checked its contents via the digital facsimile.

56 See Sewright, 'An Introduction', 659-61.

57 See Sewright, 'An Introduction', 649-57.

58 This is not to say that Charles did not selectively share his more political French poetry with his English acquaintances, some of whom may have been sympathetic to his cause. On Charles's captors and the literary milieux that they constituted, see further William Askins, 'The Brothers Orléans and their Keepers', and Derek Pearsall, 'The Literary Milieu of Charles of Orléans and the Duke of Suffolk, and the Authorship of the Fairfax Sequence', both in Charles d'Orléans in England, ed. Arn, 27-45 and 145-56. 
MSS Lansdowne and fr. 19139 do not match up, the transmission of the depoliticized anthology looks likely to have been quite broad. ${ }^{99}$ It may be that this was the standard form in which Charles's verse was met by his later medieval readers. It is worth pointing out at this juncture that, like Martin le Franc, the duke's contemporary, René d'Anjou, also celebrated Charles as a poet of love. In his Livre du cœur d'amour épris (1457), Charles's blazon and the verses written beneath it are among the coats of arms that Renés protagonist, Cueur, sees hanging in the gateway leading to the cemetery of the hospital of Love:

De Charles quint de France, roy vertueux et saige,

Fu filz du filz nommé Loÿs par droit usaige,

Qu'en son temps pour sa part tint vraiement l'eritage

D’Orleans la duchié, voirë, en apasnaige.

Aprés l'ay possidee, puis par mon hault couraige

Tins pié coy en bataille, dont souffry maint dommaige,

Car prins fuz des Anglois et mené en servaige.

Et tant y demouray qu'en aprins le langaige

Par lequel fus acoint de dame belle et saige

Et d'elle si espris qu'a Amours fis hommaige,

Dont mains beaux ditz dictié bien prisez davantaige. ${ }^{60}$

Of Charles $\mathrm{V}$ of France, a virtuous and wise king, / I was the rightful son of the son called Louis, / Who, during his lifetime, governed his inheritance truly / Of the duchy of Orleans, / which he held, indeed, in apanage. / Afterwards I owned it outright, then through my great courage / I held firm in battle, for which I suffered many an injury / For I was taken by the English and led away in servitude. / And I stayed there so long that I learned their language / Thanks to which I became acquainted with a beautiful and a wise woman / And fell in love with her so deeply that I pledged homage to Love / About which topic I have composed many beautiful poems which are all the more prized.

59 Paris, Bibliothèque de l'Arsenal, MS 2070 has not been digitized and I have not been able to check its contents. It contains a smaller selection of Charles's poetry than that found in MS fr. 19139 and is related to that book by the inclusion of a text whose only other copy is found there. The most detailed description of the Arsenal manuscript remains that in Charles d'Orléans: Poésies, ed. Champion, ixx.

6o René d'Anjou: Le livre du coeur d'amour épris, ed. Florence Bouchet (Paris, 2003), lines 1459-69. 


\section{The English Prison Poetry}

In his English Book of Love, Charles's amorous pose is ubiquitous. The depoliticization of the total corpus of the duke's prison poetry that we saw in the selections of his verse anthologized in MSS fr. 19139 and Lansdowne 380 is here taken a step further. For example, while those books transmit two pro-peace set-pieces that were written during the duke's imprisonment - the Complainte de France (co3: 'France, jadis on te souloit nommer') and ballade 115 ('Priés pour paix, doulce Vierge Marie') - these texts appear to have been found too topical for inclusion in Harley $682 .{ }^{61}$ Two of the French ballades exchanged between Charles and Philippe de Bourgogne (B129 and B130) do make a showing among the English poetry (as B111 and B113), but they appear there devoid of all topical reference as yet more love poetry. ${ }^{62}$ Indeed, France barely gets a mention in the English verse, and England gets no mention at all. ${ }^{63}$ This discrepancy derives not solely from the negative selection of texts from the total corpus of the prison poetry for compilation and translation in Harley 682. In the texts assembled in the English Book of Love, some sort of editing on the level of the line also appears to have taken place. ${ }^{64} \mathrm{On}$

61 The Complainte is discussed below. The duke's most ardent political poem, ballade 76, beginning 'Comment voy je ses Anglois esbaÿs' [How I see those English confounded!], had not yet been written: it records English military defeats in 1449 and 1453. In the context of this study of the politics of Charles's poetry, it is nevertheless worth pointing out that the virulent expression of Anglophobia in that poem is also a performance. In the envoy to the poem, Charles's addresses his work to the 'Roy des Françoys', that is, to Charles VII of France (B76: 34).

62 For an analysis of the intertwining of the languages of love and politics in these poems, see Susan Crane, 'Charles of Orleans: Self-Translation', Medieval Translator 8 (2003), 169-77.

63 See the index of proper nouns in Fortunes Stabilnes, ed. Arn, 623-24.

64 Debates on whether the English or the French verse came first tend towards the conclusion that the French verse preceded the English. See, for example, Hans H. Meier, 'Middle English Styles in Translation: The Case of Chaucer and Charles', in So Meny People Longages and Tonges: Philological Essays in Scots and Mediaeval English Presented to Angus McIntosh, ed. Michael Benskin and M. L. Samuels (Edinburgh, 1981), 367-76 (372-76). This conviction is evident in my commentary on the depoliticization of Charles's French verse in Harley 682. Thinking more broadly, however, it is important to consider, as Crane points out ('Charles of Orleans: Self-Translation', 170-71), that the French text might not always have been written before its English counterpart. It also seems likely that the project of producing manuscripts of the French and English texts 
two occasions, where the French identity of Charles's lady is specified in the French ballades, in the English poems, her origin goes unmentioned. Compare

Pource que veoir ne vous puis,

Mon cueur se complaint jours et nuis,

Belle, nompareille de France,

Et m’a chargié de vous escrire ...

(B25: 28-31)

Since I cannot see you, / My heart complains day and night, / Beautiful, peerless one of France, / And it (i.e. the heart) has charged me to write to you ...

with:

Syn Absence thus me holt \& from yow tiise

Mi hert complayneth that ye myght agrise

Hem forto here, myn owen sovl suffisaunce,

Me praiying this to write yow, lady dere ...

(B27: 1031-34)

and compare

Dangier, ...

... vous mavez mainte saison

Fait douleur a tort endurer

Et me faittes loings demourer

De la nompareille de France.

(B44: 1, 5-8)

Dangier ... / ... you have in many a season / Wrongfully made me suffer pain / And you make me stay far removed / From the peerless one of France.

with:

simultaneously involved Charles in the concurrent revision of both bodies of verse. 
A, Daunger, ...

... thou hast full many a sesoun

On why doon me endewre gret heuynes,

That dost me dwelle thus from the good princesse

Which hath no pere (such is hir happy chaunce).

(B44: 1548, 1552-55)

on why: wrongfully

The exigences of rhyme cannot be adduced in order to explain the omission of 'France' in either of these cases: 'suffisaunce' goes on to rhyme with 'Displesaunce' in ballade $27(1033,1036)$ and 'chaunce' will rhyme with 'vsaunce' in ballade $44(1555,1556)$. Biographical reasoning is likewise unsatisfactory. Charles's second wife, Bonne d'Armagnac, died sometime in the early 1430s, and the duke is sometimes thought to have taken an English lady during the last phase of his exile, as René d'Anjou has it in his Aurelian blazon. While it might be tempting to see discrepancies between the French and English verses cited above as evidence of the poet's attempts to recycle his love lyrics for a new addressee, Charles may never have had a real lady in mind when composing his poetry. ${ }^{65}$ Instead, I suggest, the decision to omit 'France' in English ballades 27 and 44 functions analogously to the selection of Charles's poetry for compilation in MSS fr. 19139, Lansdowne 380 and Harley 682; that is, it is best regarded as part of an attempt on the part of the poet to shade out questions of French allegiance in the verse received by his insular audience.

Charles's attempts to shape his English persona are clearest where he can be seen to have proceeded not simply by negative selection from among his works but also by positive adaptation. In a parallel case to those discussed above, there is one English poem that includes a reference to France where, in the corresponding French verse, France is not mentioned. In the French text (B16: 'Ma dame, vous povez savoir'), the speaker laments Dangier's theft of 'ce peu de plaisir que j'avoye' [that little bit of pleasure that I had] (refrain). Indeed, it was not little, the speaker asserts, because, through it, he could at least hope to achieve more pleasure in the future:

65 On this point, see John Fox, The Lyric Poetry of Charles d'Orléans (Oxford, 1969), 152-56. 
Non pas peu, car de bon vouloir

Content m'en devoye tenir

En esperant de recevoir

Un trop plus grant bien avenir.

Je n'y cuidoye point faillir

A la paine que g'y mettoye.

Cela me faisoit enricher

Ce peu de plaisir que j'avoye.

(B16: 17-24)

It was not little, for, with good will, / I had to be content with it, / Hoping to receive / a much greater good to come. / I did not think that I would fail / Given the pains that I invested to that end. / That enriched me, / That little portion of pleasure that I had.

The English version of the stanza just cited is set in the present tense and the speaker looks forward to his amorous struggle, which is imagined in terms of hand-to-hand combat. Since the English is especially tricky, I attempt a translation:

Not hit as small, forwhi hit suffisyng

Is vnto me in hauyng esperaunce,

Forto resceyue in aftir tyme comyng

Vnto my weele so gret an habundaunce.

I trust it shall not fayle bi such penaunce

That y woll take for Daunger threst abaft,

Which woll enriche me lo well more pen Fraunce,

The small plesere that $y$ haue to me caft.

(B16: 690-97)

It (i.e. the little pleasure) is not small, for it suffices / to give me hope / of receiving in the future / so great an abundance into my happiness. / I trust that it (i.e. the little pleasure) will not fail me through the penance that I will take on account of Daunger, as one stabbed in the back, / which (i.e. which penance) will be more plentiful in me - lo! - even than in France. Oh! The small pleasure that I have caught unto myself. ${ }^{66}$

66 Compare the partial translation offered in Fortunes Stabilnes, ed. Arn, 161-62. I read the refrain as sigh, considering it to be syntactically independent from the stanza. 
The goal here seems to be to present the suffering speaker, Charles, as the mirror image of a suffering France: during the course of his forthcoming fight with Daunger, the speaker of the English ballade will have more pains even than those now suffered by his homeland. While the image of the duke 'threst abaft' may give us pause for thought - is the implication that he, or France, has been stabbed in the back by the English? - what is crucial here, I think, is the evocation of the sacrament of penance in line 694. The idea that the French were deserving of their military defeats in the first half of the fifteenth century constituted an important aspect of the English justification for their aggression and became a historiographical commonplace. Imagining a post-Agincourt conversation between Charles and Henry V in his Chronique (1462-68), for example, the Burgundian chronicler Jean Le Fèvre de Saint-Rémy gives full vent to this rationale. Charles refuses to eat and Henry attempts to cheer him with this piece of cold comfort:

Je cognois que Dieu m’a donné la grâce d’avoir eu la victoire sur les François; non pas que je le vaille, mais je crois certainement que Dieu les a voulut pugnir; et s'il est vray ce que jen ay ouy dire, ce n'est de merveilles; car on dist que oncques plus grant desroy ne désordonnance de volupté, de péchiés et de mauvais vices, ne fut veu que règnent en France au jour d'uy. Et est pitié de l'oyr recorder, et orreur aux escoutans. Et se Dieu en est courouchiés, ce n'est pas de merveilles, et nulz ne s'en doibt esbahir. ${ }^{67}$

I recognize that God gave me the grace to have had victory over the French and that I do not deserve it. But I certainly believe that God wanted to punish them; and if what I have heard is true, it is no wonder. For it is said that greater disarray nor disorder brought about by voluptuousness, sins and evil vices were never seen than reign in France today. And it is a pity to listen to it recounted, a true horror to those hearing it. And if God grew wrathful at it, it is no wonder, and no one ought to be astounded at it.

As Coldiron points out, Charles resorts to precisely this reasoning in the Complainte de France (Co3). ${ }^{68}$ In that poem, Charles apostrophizes his

67 Jean Le Fèvre de Saint-Rémy, Chronique, ed. François Morand, Société de l'histoire de France 178 and 204, 2 vols (Paris, 1876-81), 1: 261.

68 Coldiron, Canon, Period, and the Poetry, 25. 
homeland and enumerates the causes of its current parlous state. In the second stanza of the text, the refrain (the last line cited here) takes on a particularly bitter flavour:

Scez tu dont vient ton mal, a vray parler?

Congnois tu point pourquoy es en tristesse?

Conter le vueil, pour vers toy macquiter,

Escoutes moy et tu feras sagesse.

Ton grant ourgueil, glotonnie, peresse,

Couvoitise, sans justice tenir,

Et luxure, dont as eu abondance,

Ont pourchacié vers Dieu de te punir,

Trescretien, franc royaume de France!

(Co3: 10-18)

Do you know where your trouble comes from, to speak truth? / Do you not recognize why you are in sadness? / I will tell you so I can pay my dues, / Listen to me and you will be acting wisely. / Your great pride, gluttony, sloth, / And envy - distaining justice - / And lust, of which you have had an abundance, / Have provoked God into punishing you, / Most Christian and free kingdom of France!

As was mentioned above, Charles chose not to compile an English version of this text in Harley 682. Although the poem's final stanza identifies it as a product of the poet's more passionate youth and concludes with a prayer for peace, perhaps the brief glimmers of hope that it provided for a reversal of French fortunes were thought too risky for inclusion in the English book. ${ }^{69}$ What the English text of ballade 16 shows us, though, is Charles offering a miniature version of a popular, Anglophile rationale for the French defeat for the benefit of a uniquely insular audience.

69 In the stanza of the poem following that just cited, for example, Charles comforts France: 'Ne te vueilles pour tant desesperer, / Car Dieu est plain de merci, a largesse. / Va ten vers lui sa grace demander, / Car il t’a fait, de ja pieça, promesse, / Mais que faces ton advocat Humblesse, / Que tresjoyeux sera de toy guerir' [Yet do not for this reason despair, / For God is full of mercy, plentifully so. / Go to him to ask his grace, / For long ago he promised you / So long as you make your intercessor Humility / That he will be very glad to heal you] (Co3: 19-24). 
There are other points of difference between the English and the French versions of Charles's ballade 16 which combine to constitute what I consider to be a special effort on the part of the poet to curry favour with his captors. In the first stanza of the poem, the English text adds information in order to pad out the longer metrical line. Compare

Ma dame, vous povez savoir

Les biens qu'ay euz a vous servir,

Car, par ma foy, pour dire voir,

Oncques je n'y peuz acquerir

Tant seulement un doulx plaissir

Que, sitost que je le tenoye,

Dangier le me venoit tolir,

Ce peu de plaisir que javoye.

(B16: 1-8)

My lady, you know well / The benefits that I have had in serving you, / For, by my faith, to speak truthfully, / I could never acquire / Even one sweet pleasure / That, as soon as I had it, / Dangier would not come to take from me, / That little bit of pleasure that I had.

with:

Madame, ye ought well know, to my semyng,

What ioy that y haue had or yit plesaunce

In yowre seruice for this, without gabbyng:

To gidere yet y neuyr had puysshaunce

Oon only plesere to my suffisaunce,

But even as sone as that $y$ haue it raught

Daunger birevith hit me (such is my chaunce),

The small plesere that $y$ haue to me kaught.

(B16: 674-81)

The speaker of the English text appears more hesitant and fussier than his French counterpart thanks to the introduction of parenthetical phrases (to my semyng, such is my chaunce) and the addition of redundant information (or yit plesaunce). The substitution of the conventional French phrase pour dire voir by the English without gabbyng also bespeaks a lack of poise. While throughout the Middle Ages gabben will retain the sense 'to lie' in English, by the late fourteenth century, witnesses become 
common to a meaning approaching the more modern senses of the word: 'to speak foolishly' or 'talk indiscreetly' ${ }^{\circ 0}$ In the English version of ballade 16 , we see the duke struggling with his lines and, perhaps, making himself ridiculous through the introduction of a word that slips out of his control. The lack of linguistic mastery that is evident in the English poem may well reflect the duke's imperfect grasp of English, as Arn has pointed out. ${ }^{71}$ It is also possible, I think, that Charles is attempting to turn his known identity as a second-language learner of English into a part of his poetic persona. A French prince willing to learn English is a flattering prospect, as Coldiron has noted. ${ }^{72}$ Charles's bungled English also affords him the opportunity to play the clown.

The sense that Charles might be deliberately playing up his identity as a non-native speaker of English is enhanced in the second stanza of ballade 16. Compare

Je n'en savoye nul avoir

Qui peust contenter mon desir,

Se non quant vous povoye voir,

Ma joye, mon seul souvenir.

Or m'en a fait Dangier banir,

Tant qu'il fault que loing de vous soye,

Par quoy a fait de moy partir

Ce peu de plaisir que j’avoye.

(B16: 9-16)

I knew of no possession / That might content my desire / Except when I might see you, / My joy, my only remembrance. / Now Danger has banished me from that / Such that I must be far from you, / And in so doing he has made leave from me / That little bit of pleasure that I had.

with:

I knowe no ricches in this world beyng

Which may content to lessen my grevaunce

But it be what that haue ye well demyng,

70 These glosses are drawn from the MED s. v. gabben.

71 See Mary-Jo Arn, 'Charles of Orleans and the Poems of BL MS, Harley 682', English Studies 74 (1993), 222-35.

72 See Coldiron, Canon, Period, and the Poetry, 20-24. 
Mi very ioy and sovl remembraunce,

But Daunger hath banysshid myn affyaunce

And me from yow, that now y serue of naught,

Which hath be tane out of my gouernaunce

The small plesere that y haue to me kaught.

(B16: 682-89)

The cool elegance of the French poem, in which the speaker delicately regrets the sight of his lady, is replaced in the English with an off-key innuendo. The English speaker knows no riches in the world that might lessen his pain apart from you know what (what that haue ye well demyng). But the English speaker is also less optimistic of achieving his aim. In the poems' second lines, where the French speaker considers the contentment of his desir, the English speaker has more managed expectations: he hopes to lessen his grevaunce. He also adds a rather ungracious complaint on the superfluity of his service. The end effect of Daunger's actions, we are told, is that now he serves of naught, for nothing.

Twentieth- and twenty-first-century popular culture provides us with examples of Channel-hopping stars who flaunt their linguistic otherness and (pretended?) ineptitude when away from home. We might think of Eric Cantona travelling from the French side, or of Jane Birkin from the English. I think something similar is going on in Charles's English verse, which is often rendered difficult to read as a result of its flagrantly odd syntax and lexis. The worried loquacity, the colloquialism, the more abject emotionalism and the hopeless randiness of Charles's persona in the English text of ballade 16 distinguish the duke's English from his French persona across the corpus of his bilingual prison poetry. ${ }^{73}$ The introduction of these qualities in the texts collected in Harley 682 suggests the influence of a distinctly English iteration of the modesty topos and, in particular, the talent for self-depreciation practised both by Chaucer and by his fifteenth-century followers. ${ }^{74}$ As David Lawton

73 For further contrastive examples drawn from the bilingual poetry, see Rory G. Critten, 'The Political Valence of Charles d'Orléans's English Poetry', Modern Philology 111 (2014), 339-64 (341-53).

74 On the Chaucerian vein in Charles's English poetry, see Julia Boffey, 'Charles of Orleans Reading Chaucer's Dream Visions', in Mediaevalitas: Reading the Middle Ages, ed. Piero Boitani and Anna Torti, The J. A. W. Bennett Memorial Lectures 9 (Cambridge, 1996), 43-62. See too the commentary in Fortunes Stabilnes, ed. Arn, 39-45. Charles's Chaucerianism becomes particularly clear in those portions of the English Book of Love for which there is no 
has shown, when post-Chaucerian writers adopted a pose of 'dullness', they did so because they found that it allowed them to engage in political manoeuvring. ${ }^{75}$ I suggest that something like this is going on in Charles's English verse, where the poet attempts to craft a persona that he thinks will find favour with his audience. Here I expand upon my earlier work on Charles, in which I posited that, in his English poetry, the duke was keen to correct reports of his 'cauteleux', or tricky, disposition that might be mobilized in arguments against his release. ${ }^{76}$ By presenting himself as an almost naturalized, obsessively amorous, faintly risible Frenchmanat-court, I contend, Charles hoped to present the English with the image of a man who was, if not quite trustworthy, then at least unthreatening.

\section{Out of Europe}

The context afforded by the poetic policy of appeasement that I have described provides a fresh set of parameters in which to consider the parallel texts of ballade 35, from which I quoted at the close of my introduction. In both versions of this poem, a speaker describes the pleasures that he derives from a mirror bought from the God of Love in which the beauty of his lady is reflected. Differences between the two texts are consonant with those already identified as characteristic of the divergence between the French and English poetry. Unlike the French text, for example, the English text has a four-line envoy in which the speaker ruefully adduces his abundance of woe and compares his situation to that of Job (B35: 1277-80). Prior to this, the inclusion of a filler phrase has tipped the English text into comedy. In the French version, writing of the pleasure with which his heart looks into his mirror, the speaker asserts that

mon cueur n’a jamais santé

Fors quant il y peut regarder

French equivalent, which I do not touch on here. For summary and analysis of these portions of the work, see Mary-Jo Arn, 'The English Poetry of Charles of Orleans', Dutch Quarterly: Review of Anglo-American Letters 8 (1978), 108-21.

75 See David Lawton, 'Dullness and the Fifteenth Century', ELH 54 (1987), 761-99.

76 See Critten, 'The Political Valence of Charles d'Orléans's English Poetry'. There I offer a dossier of reports attesting to the distrust with which the duke was regarded both by Henry V and his brother, Humphrey, duke of Gloucester (356-61). The dossier is reproduced in my Author, Scribe, and Book, 169-75. 
Des yeulx de Joyeuse Plaisance.

(B35: 14-16)

My heart is never well / Except when he can gaze in it / With the eyes of Joyous Pleasure.

In the English poem, by contrast, inviting us to imagine his lady looking back at him from within the mirror, the speaker seems surprised to find her smiling:

in myn hert nys ioy in no degre

More then biholde how she is ingoodly,

With gladsom eyen levting no poynt aslope.

(B35: 1263-65)

ingoodly: very beautiful

She greets him with gladsome eyes, levting no poynt aslope - that is, without a frown. This lady, it seems, gives the speaker an unusually positive reception. A series of alterations contributing to Charles's selfdeprecating self-portraiture also occurs at the close of the English text. ${ }^{77}$

The portion of the poem that concerns me now, though, is its opening. It is here that the geographies of the two versions of ballade 35 part ways so strikingly. Compare

J'ay ou tresor de ma pensee

Un mirouer qu’ay acheté.

Amour en l'annee passee

Le me vendy de sa bonté,

Ou quel voy tousjours la beauté

77 Whereas in the French ballade Charles says he will lock up his mirror 'ou coffre de ma souvenance / Pour plus seurement le garder' [in the chest of my memory / to keep it more safely] (B35: 25-26), in the English poem, the speaker is more fastidious, expressing his intention to 'rolle it vp to kepe it more clenly / (To eftsone that me lust as for hit grope) / In tresoure of my thought to kepe it drye' (B35: 1273-75). By this point in the English poem, the mirror seems to have become a portrait, a 'likyng', which might presumably be rolled up (B32: 1259). In any case, the English speaker here manifests a disarmingly practical concern with the preservation of his toy. Despite his frequent reaching for it and, apparently, crying over it, it should not be allowed to get grubby and damp. 
De celle que l'en doit nommer

Par droit la plus belle de France.

Grant bien me fait a m'y mirer

En attendant Bonne Esperance.

(B35: 1-9)

I have in the treasury of my thought / A mirror that I bought. / Love, last year / Sold it to me out of his goodness, / And in it I can always see the beauty / Of the one that must be called / Rightfully the most beautiful in France. / Great good it does me to gaze in it / While awaiting Good Hope.

with:

Within the tresoure haue y of my thought A myrroure which y bought but late, parde, Of God of Loue (as when forgete y nought This yere apast!) which solde it of bounte To me, wherein ay se $y$ the bewte

Of hir that ought ben callid wel trewly

The most fayrist bitwene this and Europe.

Gret good, god wott, hit doth me in to prye In abiding my gladsom in good hope.

(B35: 1250-58)

Again, the word 'France' appears to have been tampered with. The resulting divergence derives in part from the more extravagantly emotional atmosphere of Charles's English verse, to which I have already alluded: while the double superlative is more common in Middle than Modern English, it is nevertheless noteworthy that the poet deploys it here ('most fayrist'). Given what we now know about Charles's sensitivity to the links between poetry, place and politics, however, the duke's evocation of Europe deserves closer consideration. I offer the following brief analysis as a coda to the foregoing argument.

\section{Charles d'Orléans, Europhobe?}

From antiquity into the early modern period, the use of the words Europe and Europa was limited primarily to contexts of formal geographic description where the traditional tripartite division of the world into 
Africa, Asia and Europe was at issue. ${ }^{78}$ Charles's deployment of 'Europe' in the English text of balade 35 comes at a time when the old word is beginning to gather to itself some of the meanings of the term that it would eventually replace: Christendom. As Denys Hay showed some time ago, the birth of Europe as an idea might be traced back to a series of developments that came to a head in the fourteenth and fifteenth centuries. The decline of the universal church, the loss of Middle Eastern territories that had belonged to Christian kings and the expansion of Christian territory on the Continent meant that the geographical boundaries of Christianity and Europe coincided more closely than ever before during this period; simultaneously, the new type of portolan sea charts offered more accurate representations of coastlines than had hitherto been available, allowing the inhabitants of Europe a new, external perspective on their region..$^{79}$ In setting up a clear distinction between 'Europe' and 'this' (England), Charles seems to be attempting to position this nascent idea of Europe vis-à-vis the much older notion of English isolation, which can be traced back at least as far as the Romans.

For Virgil, the Britons were a distant nation, 'wholly sundered from all the world', as he had it in his Eclogues; in his Natural History, Pliny the Elder described Britain as an island tagged onto the Continent whose total exploration remained to be undertaken; and even after its incorporation into the Roman Empire, Britain's identity as a distant outpost was confirmed by Tacitus, who in his Agricola presented the sea as a divider between Britain and civilisation. ${ }^{80}$ The Anglo-Saxons took their sense of their place in the world from these authors; as Nicholas Howe has pointed out, however, this was a position from which they could

78 The DMF and the Corpus of Middle English Prose and Verse (http://quod. lib.umich.edu/c/cme/) s. vv. Europe and Europa give examples of vernacular usage. One exception to this general rule is the deployment of the word Europa in Latin to denote the extent of Charlemagne's empire in the eighth and ninth centuries. See further Heinz Gollwitzer, 'Zur Wortgeschichte und Sinndeutung von "Europa", Saeculum 2 (1951), 161-72.

79 See Denys Hay, "Europe" and "Christendom": A Problem in Renaissance Terminology and Historical Semantics', Diogenes 5 (1957), 45-55. On the effects of the portolan map on the self-perception of the English, see Alfred Hiatt, "'From Hulle to Cartage': Maps, England, and the Sea, in The Sea and Englishness in the Middle Ages: Maritime Narratives, Identity and Culture, ed. Sebastian I. Sobecki (Cambridge, 2011), 133-57.

80 For these citations and further discussion, see Alfred Hiatt, 'From Pliny to Brexit: Spatial Representation of the British Isles', postmedieval 7 (2016), 511-25. 
act self-assertively as well as submissively towards Rome. ${ }^{81}$ Much closer to Charles's own time, the commitment of the English to their isolated status and their determination to use this to their political advantage had been seen at the Council of Constance (1418-1418). At that gathering, the English delegates successfully saw off the attempt of the French party to fold the English bargaining group into that of the German nation, which also included the Hungarians, Czechs, Danes and Swedes. The English delegation was numerically far less significant than those sent by the other French, German and Italian nationes alongside whom the English were nevertheless entitled to an equally weighted vote. But the English argued passionately in favour of their right to individual representation on the grounds of their extensive territories and their difference among themselves as was witnessed by their identities as the speakers of five different languages: English, Welsh, Irish, Gascon and Cornish. ${ }^{82}$

Clearly, arguments adducing the geographical and linguistic exceptionalism of the English in the first half of the fifteenth century took place against a backdrop whose complexity was at odds with such claims. French remained current in England well into the fifteenth century and the porosity of the boundary between England and France was demonstrated by the persistence of an English settlement in Normandy that outlasted Charles's English imprisonment. ${ }^{83}$ The desire to individuate England from the Continent ran alongside a desire to incorporate the Continent into England. I think that some of the tensions resulting from this contradiction can be felt in Charles's use of the word Europe in English ballade 35. The scarcity with which the term is used beyond the context of formal geographic description argues in favour of its

81 See Nicholas Howe, 'Rome: Capital of Anglo-Saxon England', Journal of Medieval and Early Modern Studies 34 (2004), 147-72.

82 The classic account of this conflict is Louise R. Loomis's essay, 'Nationality at the Council of Constance: An Anglo-French Dispute,', American Historical Review 44 (1939), 508-27. More recently, see too the account of the extensive cultural exchange made possible by the Council of Constance by David Wallace in the concluding chapter to his edited Europe: A Literary History 1348-1418, 2 vols (Oxford, 2016), 2:655-82.

83 On the continuing use of French in fifteenth-century England, see Rory G. Critten, 'The Manières de langage as Evidence For the Use of Spoken French Within Fifteenth-Century England, Forum for Modern Language Studies 55 (2019), 121-37. On the English settlement in Normandy, see C. T. Allmand, Lancastrian Normandy, 1415-1450: The History of a Medieval Occupation (Oxford, 1983). 
deliberate deployment by the poet; one reason for his use of the word might have been cynically to flatter the isolationist egos of his captors by presenting them with a mental map on which - against all the available evidence - the English were set apart from the world beyond the Channel. In the foregoing pages I have argued that the duke attempted to mollify his insular audience throughout the writing that he directed to them. If his depiction of a distant Europe can be attached to this purpose, then Charles d'Orléans might well be considered the first manipulator of Europhobia among the English.

Historians of the idea of Europe stress the importance of the Continent's unstable eastern border as the zone in which European identities, through opposition, have been crafted. Following Hay, Jacques Le Goff demonstrates how the word Europe crystallizes in moments of conflict on these marches, between Greeks and Persians, between the western and the eastern empires, between Christians and Mongols, and Christians and Turks. This long trend culminates in pope Pius's composition of his twin tracts, Europa (1458) and Asia (1461): the first tract to bear the name of the western Continent is paired with an examination of its eastern other. ${ }^{84}$ Other frontiers were crucial too, such as the borderland between Christian and Arab Spain. In English ballade 35, Charles seems to have noticed a smaller junction but one which, for his captors, could nevertheless hold special - and lasting - meaning. In his use of the unusual word Europe in this poem, the duke again manifests his remarkable ability to craft persuasive poetic identities that mix the discourses in the midst of which he found himself and his own very public biography.

84 See Jacques Le Goff, L’Europe, est-elle née au Moyen Âge? (Paris, 2003), 11. 